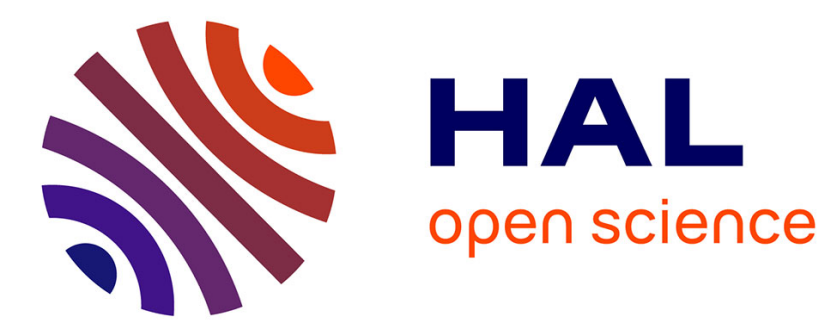

\title{
Total Femur Replacement: Primary procedure for treatment of malignant tumours of the femur
}

S. Kalra, A. Abudu, H. Murata, R.J. Grimer, R.M. Tillman, S.R. Carter

\section{To cite this version:}

S. Kalra, A. Abudu, H. Murata, R.J. Grimer, R.M. Tillman, et al.. Total Femur Replacement: Primary procedure for treatment of malignant tumours of the femur. EJSO - European Journal of Surgical Oncology, 2010, 36 (4), pp.378. 10.1016/j.ejso.2009.11.002 . hal-00576165

\section{HAL Id: hal-00576165 \\ https://hal.science/hal-00576165}

Submitted on 13 Mar 2011

HAL is a multi-disciplinary open access archive for the deposit and dissemination of scientific research documents, whether they are published or not. The documents may come from teaching and research institutions in France or abroad, or from public or private research centers.
L'archive ouverte pluridisciplinaire HAL, est destinée au dépôt et à la diffusion de documents scientifiques de niveau recherche, publiés ou non, émanant des établissements d'enseignement et de recherche français ou étrangers, des laboratoires publics ou privés. 


\section{Accepted Manuscript}

Title: Total Femur Replacement: Primary procedure for treatment of malignant tumours of the femur

Authors: S. Kalra, A. Abudu, H. Murata, R.J. Grimer, R.M. Tillman, S.R. Carter

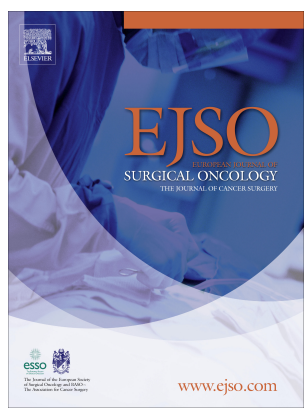

PII:

S0748-7983(09)00504-6

DOI:

10.1016/j.ejso.2009.11.002

Reference: YEJSO 2913

To appear in: European Journal of Surgical Oncology

Received Date: 24 September 2009

Accepted Date: 5 November 2009

Please cite this article as: Kalra S, Abudu A, Murata H, Grimer RJ, Tillman RM, Carter SR. Total Femur Replacement: Primary procedure for treatment of malignant tumours of the femur, European Journal of Surgical Oncology (2009), doi: 10.1016/j.ejso.2009.11.002

This is a PDF file of an unedited manuscript that has been accepted for publication. As a service to our customers we are providing this early version of the manuscript. The manuscript will undergo copyediting, typesetting, and review of the resulting proof before it is published in its final form. Please note that during the production process errors may be discovered which could affect the content, and all legal disclaimers that apply to the journal pertain. 
Title

Total Femur Replacement: Primary procedure for treatment of malignant tumours of the femur

Authors

Kalra $S^{a}$, Abudu A $A^{a}$, Murata $\mathbf{H}^{\mathrm{a}, \mathrm{b}}$, Grimer $\mathbf{R J}^{\mathrm{a}}$, Tillman $\mathbf{R M}^{\mathrm{a}}$, Carter $\mathrm{SR}^{\mathrm{a}}$

\section{Institution Details:}

${ }^{\text {a }}$ Royal Orthopaedic Hospital NHS Trust

Bristol Road South,

Birmingham B31 2AP

England

Telephone: (+44) (0)121 6854037

Fax: (+44) (0)121 6854146

E-mail: seggy.abudu@roh.nhs.uk 


\section{Author Details:}

First Author:

Mr. S Kalra MRCS

Specialist Registrar in Trauma and Orthopaedics, All Wales Rotation.

${ }^{a}$ Royal Orthopaedic Hospital, Birmingham, UK

Mr. A Abudu FRCS

Consultant in Orthopaedic Oncology

${ }^{a}$ Royal Orthopaedic Hospital, Birmingham, UK

Mr. H Murata MD, PhD

${ }^{a}$ Research Fellow in Orthopaedic Oncology - Royal Orthopaedic Hospital, Birmingham,

UK and

${ }^{\mathrm{b}}$ Assistant Professor in Orthopaedic Surgery - Graduate School of Medical Science, Kyoto Perfectural University of Medicine, Kyoto, Japan.

\section{Mr. RJ Grimer FRCS}

Consultant in Orthopaedic Oncology

${ }^{a}$ Royal Orthopaedic Hospital, Birmingham, UK 
Mr. RM Tillman FRCS

Consultant in Orthopaedic Oncology

${ }^{a}$ Royal Orthopaedic Hospital, Birmingham, UK

\section{Mr. SR Carter FRCS}

Consultant in Orthopaedic Oncology

${ }^{a}$ Royal Orthopaedic Hospital, Birmingham, UK

\section{Academic affiliations:}

a. Orthopaedic Oncology Department, Royal Orthopaedic Hospital, Bristol Road South, Birmingham B31 2AP, UK.

b. Graduate School of Medical Sciences, Kyoto Prefectural University of Medicine, 6028566 Kyoto, Japan. 
Kalra S et al 4

\begin{abstract}
We present our experience of treating patients with tumours involving the whole femur with excision and total femur endoprostheses over the last 30 years (1975 to 2005). There were 26 consecutive patients (14 men and 12 women). Average age was 40 years (14 82 years) at the time of surgery and 21 of the patients had primary malignant bone tumours with five having the procedure for metastases. 11 patients were still alive of which nine were free of disease at the time of review at a mean follow-up of 57 months (3 to 348). The overall patient survival at 10 years was $37 \%$. The survival of patients with a primary localised tumour was $50 \%$ at 10 years.

Revision of the prostheses was necessary in two patients (at 110 and 274 months) because of recurrent dislocation and aseptic loosening. Amputation was necessary in two patients but long-term limb survival was $92 \%$ at 10 years. Nine patients alive with no evidence of disease had a mean MSTS functional score of $72 \%$.
\end{abstract}

\title{
Level of Evidence:
}

Therapeutic Study, Level - IV (Case series) 
Kalra S et al 5

\section{Introduction}

Tumours involving the whole femur present a challenge when limb preservation is considered. These tumours are often large and resection involves removal of the whole femur with disruption of the hip abductor mechanism. Extensive soft tissue dissection and reconstruction of the joint above and below are required.

The options for treating such patients include amputation by hip disarticulation or limb preserving surgery. Limb preserving surgery is better accepted by patients, is more cost effective in the long term, and is associated with significantly lower oxygen consumption and energy requirements per meter walked compared to amputation ${ }^{1,2}$. Moreover, patients' survival is not improved by amputation ${ }^{3}$. The choices available for reconstruction in such patients include the use of endoprostheses, allograft or rotationplasty ${ }^{4-12,18}$.

We carried out a retrospective review of patients treated with Total Femur Endoprosthetic Replacement (TFEPR) at our centre over the past 30 years to identify the factors which affect survival, complications and function following TFEPR. 


\section{Materials and Methods}

\section{Data Collection and Ethics:}

This was a retrospective analysis of data which had been collected prospectively onto our oncology database with further reference to patient charts and radiographs where necessary. Institutional review board ethical approval was granted prior to the study being undertaken.

Tumour diagnosis, treatment and outcome data was obtained from the database.

Functional outcomes were collected on surviving patients using the revised Musculoskeletal Tumour Society (MSTS) system $^{15}$ and the Toronto Extremity Scoring System (TESS) scores $^{16}$.

\section{Patients:}

Total femoral replacement was indicated for patients with tumour involving all or most of the femur and in whom no other reconstructive option was deemed feasible. 26 patients (14 men and 12 women; mean age: 40 years, range: $14-82$ years)

underwent this procedure over 30 years. The oncological diagnoses in these patients were: Osteosarcoma in 10 patients, Chondrosarcoma in 5, Ewing's sarcoma in 2, Malignant Fibrous Histiocytoma in 1, Leiomyosarcoma in 1, Fibrosarcoma in 2 and Secondary Bone Metastases in 5 patients. Three of the 21 patients with primary bone tumours had lung metastases at the time of diagnosis. These three and the five with secondary bone metastases were considered to be palliative resections whilst the others were treated with curative intent. 
The operation involved disarticulation of the hip and knee with removal of the entire femur, surrounding muscles involved with the tumour, while preserving the neurovascular bundle in all cases. In four patients who had inadvertent prior intramedullary nailing for the treatment of a pathological fracture of the femur, the nail was removed with the resected bone and the entry portal and tract were also excised (Figures-1a to1c).

\section{Surgical Procedure:}

A custom made cemented total femur endoprosthesis (Stanmore Implants ${ }^{\circledR}$ ) was used in 24 patients and a modular cemented total femur endoprosthesis (Stanmore Implants ${ }^{\circledR}$ ) was used in two patients. The modular prostheses only being available more recently and being used for patients with metastatic disease to avoid the delay in manufacturing a custom implant.

The knee joint was reconstructed with a fixed hinge prosthesis in all but two patients and the hip was reconstructed with either a 32mm metal on high molecular weight polyethylene cup or more recently with a unipolar head which allowed the use of larger femoral heads with greater stability.

\section{Adjuvant Treatment:}

Patients had chemotherapy and radiotherapy appropriate for their diagnosis. 


\section{Statistics:}

Statistical analysis included descriptive statistics and analytical statistics including Kaplan Meier survival analysis.

\section{Results}

\section{Patient survival:}

Kaplan Meier survival curves are shown in Figure-2. Survival of the patients was related to their oncologic diagnosis. None of the eight patients with metastases at diagnosis undergoing palliative resection were alive at long followup. However, survival of patients with a primary malignant bone tumour without metastases was $50 \%$ at 5 years. Eleven patients were alive with an overall mean follow-up of 105 months (range 9 to 348), nine patients being free of disease.

\section{Local recurrence:}

Local recurrence was seen in patients with primary osteosarcoma (one), primary chondrosarcoma (one) and metastatic renal cell carcinoma (one). No local recurrence was seen in the three patients who had a primary malignant bone tumour but had been inadvertently treated with an intramedullary nail. Local recurrence was treated with surgery and adjuvant treatment while amputation was required in one patient. 


\section{Limb survival:}

Complications that led to amputation occurred in patients with deep infection (one) and local recurrence (one). Limb survival using amputation as the end point was $92 \%$ at 10 years.

Complications that led to revision of the prosthesis were aseptic loosening of the acetabular cup (one) and recurrent dislocation of the hip (one). The survival of the prosthesis without revision surgery was $100 \%$ at 5 years and $80 \%$ at 10 years.

\section{Complications:}

Complications which did not impact on limb or prosthetic survival were dislocations in the early postoperative period (three) which resolved with appropriate muscle rehabilitation, two wound infections which resolved with appropriate antibiotics and one foot drop which recovered spontaneously. One deep infection required amputation.

\section{Functional outcomes:}

The function of the salvaged limbs was assessed using the revised Musculo-Skeletal Tumour Society (MSTS) rating system ${ }^{15}$. This system assesses 6 parameters on a 5 point scale ( 1 to 5 with 5 being no limitation). Nine patients who had no evidence of disease at last follow-up were assessed at mean follow-up of 125 months (range: 8 - 348). The mean functional score was $21.8(14-29)$. The scores for the individual components are summarized in Table-1. Five of the nine patients who were alive with no evidence of disease also had TESS scores. The mean TESS scores were 52.4\% (range: 20-86). 


\section{Discussion}

The last few decades have witnessed increased popularity and wider acceptance of endoprosthetic replacement in treating patients with malignant conditions of the bone due to the availability of effective chemotherapy, improved prosthetic design, availability of modular endoprosthesis and increasing experience in the use of these implants.

Total Femur Endoprosthetic Replacement is a major surgical reconstructive procedure for patients with a bone tumour involving the entire femur. The procedure is challenging both for the surgeon and equally for the patient.

The patient needs intensive rehabilitation after the procedure as all muscle attachments of the femur are detached although in selected cases attempts were made to reattach the hip abductors. This has been emphasised in the literature ${ }^{7}$.

\section{Limitations:}

A major limitation of this study was the length of time over which the data was accrued. This is because total femur replacement is not a common procedure. It is rarely needed, and most patients with a bone tumour can be treated with a less extensive form of reconstruction. We have only been able to evaluate the function in the survivors. However, we believe that the function would have been similar in those who did not survive their disease. 


\section{Literature review:}

We did an extensive literature review and compared the outcomes in this study with those by other authors for this complex reconstructive procedure (Table-2).

Reported results of total femur endoprosthetic replacement have demonstrated the relative success of the procedure in terms of limb salvage but relatively poor functional outcomes. The main problems reported by most authors are the relative lack of muscles especially the abductors of the hip and quadriceps in the knee. Even so, there are psychological and rehabilitative advantages of limb preserving surgery over amputation ${ }^{17}$. Our results show that in the majority of patients the goal of limb salvage is achievable with good long term prosthetic (80\%) and limb survival (92\%). However, the oncologic diagnosis is the major determinant of patient survival.

\section{Soft tissue reconstruction:}

Morris et al emphasized the importance of maintaining the proximal and distal muscles if good or excellent results are to be achieved. They suggested that reattachment of the abductors to the endoprosthesis often fails and therefore they suture the abductors to the fascia lata. They also emphasised that the rectus femoris should be saved, if possible ${ }^{7}$. In our study patients reported very good psychological acceptance after total femur replacement with a mean score of 4.5 out of 5 despite having poor gait patterns which are primarily due to the lack of good abductor muscle attachment. 


\section{Hip dislocation:}

Hip dislocation is a common complication reported after total femur replacement. This is probably due to the lack of functional abductor musculature and the long lever arm of the total femur replacement. In non-tumour cases this can be as low as $12 \% .{ }^{21}$ It was comparably low at $11 \%$ in the present series. We believe that a rotating hinge design at the knee should be avoided in patients with total femur replacement since rotation at the knee can lead to hip dislocation and we have seen aseptic loosening of the tibial implant only on one occasion at 22 years. Also, we have noticed a lower dislocation rate since we stopped replacing the acetabulum routinely; we now recommend hemiarthroplasty of the hip whenever possible since this allows the use of a larger femoral head.

\section{Infection:}

The deep infection rate in this series was $7 \%$ and similar to the series of Nerubay et al. ${ }^{8}$. Superficial infections were treated with antibiotics and deep infections with two stage revisions if the patients general condition allowed it.

\section{Aseptic loosening:}

Aseptic loosening rate of $3.6 \%$ in our series was comparable to non-tumour series ${ }^{21}$. Loosening occurred in one patient at the acetabular cup which was revised twice and once at the acetabular cup and the tibial stem when the whole prosthesis was revised. This may be due to decreased muscle forces placed on the implants in patients with malignant bone tumours who have undergone muscle resection as part of their tumour operation. 


\section{Local recurrence:}

Local recurrence is a common problem with tumour resection and total femur endoprosthetic replacement since the patients often have large tumours. In our series this was low (11\%) compared to the literature. This is attributable to better adjuvant treatment in the present time. The incidence of local recurrence has been found to be inversely proportional to the effectiveness of chemotherapy ${ }^{22,23}$ and effective chemotherapy will decrease its incidence even in marginal excisions. ${ }^{23}$

\section{Conclusion:}

We believe that our series presents the results of what can be expected in the long term for patients with malignant bone tumours who require total femur endoprosthetic replacement. This form of reconstruction provides predictable results after excisions of the femur for malignant tumours. The complications are comparable to those for similar procedure performed for non-tumour cases even though those with a tumour have more muscle resection and are immunologically challenged from adjuvant chemotherapy. A long term prosthetic survival of $80 \%$ and long term limb survival of $92 \%$ in this series would imply that this procedure is an excellent method of limb salvage for massive excisions of the femur for primary bone tumour. In those with secondary metastasis this can be a viable palliative procedure to enhance the quality of life of the patient. 


\section{References}

1. Grimer RJ., Carter SR., Pynsent PB. The cost-effectiveness of limb salvage for bone tumours. J Bone Joint Surg Br.1997; 79-B/4: 558-561.

2. Otis JC., Lane JM., Kroll MA. Energy cost during gait in osteosarcoma patients after resection and knee replacement and after above-knee amputation. J Bone Joint Surg Am. 1985; 67-A/4: 606-610.

3. Gebhardt MC., Goorin A., Traina J., et al. Long-term results of limb salvage and amputation in extremity osteosarcoma. In Yamamuro T (ed). New Developments for Limb Salvage in Musculoskeletal Tumours. New York: Springer; 1989: 99-109.

4. Buchman J. The femur and knee joint replacement with a vitallium endoprosthesis. Bull. Hosp. Joint Dis. 1965; 26: 21-34.

5. Mankin HJ., Gebhardt MC., Jennings LC., et al. Long-term results of allograft replacement in the management of bone tumours. Clin Orthop 1996; 324: 86-97.

6. Marcove R., Lewis M., Rosen G., Huvos AG. Total femur and total knee replacement. Clin Orthop 1977; 126: 147-152.

7. Morris HG., Capanna R., Campanacci M., Del Ben M., Gasbarrini A., Modular endoprosthetic replacement after total resection of the femur for malignant tumour. Intern Orthop 1994; 18: 90-95.

8. Nerubay J., Katznelson A., Tichler T et al. Total femoral replacement. Clin Orthop 1988; 229: 143-148. 
9. Ottolenghi C. Massive Osteoarticular bone grafts: transplant of the whole femur. $J$ Bone Joint Surg Br. 1966; 48-B: 646-659.

10. Steinbrink K., Engelbrecht E., Fenelon G. The total femoral prosthesis: a preliminary report. J Bone Joint Surg Br. 1982; 64-B: 305-312.

11. Hardes J, Gosheger G, Vachtsevanos L, Hoffmann C, Ahrens H, Winkelmann W. Rotationplasty type B1 versus type BIIIa in children under age of ten years. Should the knee be preserved? J Bone Joint Surg Br. 2005; 87(3): 395-400.

12. Winkelmann WW. Type-B-IIIa rotationplasty: an alternative operation for the treatment of malignant tumors of the femur in early childhood. J Bone Joint Surg Am. 2000; 82(6): 814-828.

13. Enneking WF., Spanier SS., Goodman MA. A system for the surgical staging of musculoskeletal sarcoma. Clin Orthop 1980; 153: 106-119.

14. Kaplan EL., Meier P. Nonparametric estimation from incomplete observations. $J$ Am Stat Assoc 1958; 53: 457-481.

15. Enneking WF., Dunham W., Gebhardt MC., Malawar M., Pritchard DJ. A system for the functional evaluation of reconstructive procedures after surgical treatment of tumours of the musculoskeletal system. Clin Orthop 1993; 286: 241-245.

16. Davis AM, Wright JI, Williams C, Bombardier C, Griffin A, Bell RS. Development of a measure of physical function for patients with bone and soft tissue sarcoma. Quality of Life Research 1996; 5: 508-516.

17. Rougraff BT, Simon MA, Kneisl JS, Greenberg DB, Mankin HJ. Limb salvage compared with amputation of osteosarcoma of the distal femur. J Bone Joint Surg Am. 1994; 76-A/5: 649-656. 
18. Horowitz SM, Glasser DB, Lane JM, Healey JH. Prosthetic and extremity survivorship after limb salvage for sarcomas: How long do the reconstructions last ? Clin Orthop 1993; 293: 280-286.

19. Zeegen EN, Aponte-Tinao LA, Hornicek FJ, Gebhardt MC, Mankin HJ. Survivorship analysis of 141 modular metallic endoprostheses at early followup. Clin Orthop 2004; 420: 239-250.

20. Schindler OS, Cannon SR, Briggs TWR, et al. Use of extendable total femoral replacements in children with malignant bone tumours. Clin Orthop Relat Res 1998; 357: 157-70.

21. Berend KR, Lombardi AV, Mallory TH, Adams JB, Dodds KL. Total femoral arthroplasty for salvage of end-stage prosthetic disease. Clin Orthop Relat Res 2004; 427: 162-170.

22. Simon MA, Nachman J. The clinical utility of preoperative therapy for sarcomas. J Bone Joint Surg Am. 1986; 68-A: 1458-1463.

23. Grimer RJ, Taminiau AM, Cannon SR. Surgical outcomes in osteosarcoma. $J$ Bone Joint Surg Br. 2002; 84-B: 395-400

24. Present DA, Kuschner SH. Total femur replacement. A case report with 35-year followup study. Clin Orthop Relat Res 1990; 251: 166-7.

25. Ward WG, Yang RS, Eckardt JJ: Total femoral endoprosthetic reconstruction. Clin Orthop Relat Res 1995; 316: 195-206

26. Mankin HJ, Hornicek FJ, Harris M. Total Femur Replacement Procedures in Tumor Treatment. Clin Orthop Relat Res 2005; 438: 60-64. 
27. Friesecke C, Plutat J, Block A. Revision arthroplasty with use of a total femur prosthesis. J Bone Joint Surg Am. 2005; 87(12): 2693-2701.

28. Ahlmann ER, Menendez LR, Kermani C, Gotha H. Survivorship and clinical outcome of modular endoprosthetic reconstruction for neoplastic disease. $J$ Bone Joint Surg Br.. 2006; 88-B:790-5. 
Figure and Table Legend

Figure-1a: A 31 years old woman presented with a pathological fracture of the proximal femur.

Figure-1b: Proximal femoral fracture was inadvertently nailed. Subsequent histologic examination confirmed chondrosarcoma.

Figure-1c: Treated with complete excision of the femur and total femoral endoprosthetic replacement. The patient is alive with no evidence of disease at two years.

Figure-2: Kaplan Meier survival curve for all patients.

Table-1: MSTS functional scoring

Table - 2: Outcomes in Total Femoral Endoprosthetic Replacements in the literature and the present study 


\begin{tabular}{|lcll|}
\hline Score & Mean & Range & Percentage \\
Pain & 3.7 & $2-4$ & $74 \%$ \\
Function & 3.3 & $3-5$ & $66 \%$ \\
Walking & 3.4 & $2-5$ & $68 \%$ \\
Support & 3.7 & $3-5$ & $74 \%$ \\
Gait & 3.1 & $1-5$ & $62 \%$ \\
Emotion & 4.5 & $4-5$ & $90 \%$ \\
\hline Overall & 21.8 & $14-29$ & $72.6 \%$ \\
\hline
\end{tabular}

Table-1 Functional scoring: MSTS scoring 


\begin{tabular}{|c|c|c|c|c|c|c|c|}
\hline $\begin{array}{l}\text { Study } \\
\text { (Reference) }\end{array}$ & $\begin{array}{l}\text { No. of } \\
\text { patients }\end{array}$ & Diagnosis & $\begin{array}{l}\text { Oncologic } \\
\text { survival }\end{array}$ & $\begin{array}{l}\text { Followup } \\
\text { (years) }\end{array}$ & $\begin{array}{l}\text { Limb / } \\
\text { Prosthetic } \\
\text { survival }\end{array}$ & $\begin{array}{l}\text { Functional } \\
\text { outcome }\end{array}$ & Complications \\
\hline 6 & 19 & Tumour & $\begin{array}{l}68.4 \% \text { at } \\
17.5 \text { months }\end{array}$ & 1.5 & $\begin{array}{l}\text { Amputa- } \\
\text { tion (5) }\end{array}$ & $\begin{array}{l}\text { Hip - good } \\
\text { Knee - poor; } \\
\text { Poor gait - } \\
\text { Extremity behaved } \\
\text { like a } \\
\text { 'weak polio leg' }\end{array}$ & $\begin{array}{l}\text { Wound (3), local } \\
\text { recurrence (2), } \\
\text { Femoral Artery } \\
\text { thrombosis (1), } \\
\text { Infection (3), hip } \\
\text { dislocation (1) }\end{array}$ \\
\hline 10 & 28 & Mixed & $\begin{array}{l}50 \% \text { at } 1- \\
\text { year }\end{array}$ & 3 & $\begin{array}{l}86 \% \text { at } 3 \\
\text { years }\end{array}$ & $\begin{array}{l}\text { Hip-satisfactory } \\
\text { Knee- poor }\end{array}$ & $\begin{array}{l}\text { Infections } \\
\text { (11) }\end{array}$ \\
\hline 8 & 19 & Tumour & $\begin{array}{l}36.8 \% \text { at } 4 \\
\text { years }\end{array}$ & $\begin{array}{l}4 \text { (longest } \\
8 \text { years) }\end{array}$ & $\begin{array}{l}44 \% \text { at } 4 \\
\text { years }\end{array}$ & $\begin{array}{l}\text { Excellent (5), } \\
\text { Good (9), Fair (3), } \\
\text { Poor (2) }\end{array}$ & $\begin{array}{l}\text { Amputation due to } \\
\text { deep infection (1), } \\
\text { wound (9) }\end{array}$ \\
\hline 24 & 1 & Tumour & 35 years & 35 & 32 years & $\begin{array}{l}\text { Ambulation with } \\
\text { walker }\end{array}$ & Possible infection \\
\hline 25 & 21 & Mixed & $\begin{array}{l}2 \text { years in } \\
\text { survivors }\end{array}$ & $\begin{array}{l}2 \text { (longest } \\
10 \text { years) }\end{array}$ & $\begin{array}{l}\text { Hip } \\
\text { disarticulati } \\
\text { on (3) }\end{array}$ & $\begin{array}{l}\text { Good (7), Fair( } 9) \text {, } \\
\text { Poor (3); Younger } \\
\text { patients }(<60) \text { did } \\
\text { better than older } \\
\text { ones }(>60)\end{array}$ & $\begin{array}{l}\text { Local recurrence } \\
\text { (2), } \\
\text { Infection (4), hip } \\
\text { dislocation (2), } \\
\text { internal malrotation } \\
(1),\end{array}$ \\
\hline 20 & $\begin{array}{l}6 \\
\text { (children) }\end{array}$ & Tumour & $\begin{array}{l}83 \% \text { at } 5 \\
\text { years }\end{array}$ & 5 & $\begin{array}{l}100 \% \text { limb } \\
\text { survival at } \\
5 \text { years }\end{array}$ & MSTS - 77.3\% & $\begin{array}{l}\text { Deep infection (1), } \\
\text { Revisions (5) }\end{array}$ \\
\hline 21 & 59 & $\begin{array}{l}\text { Non- } \\
\text { tumour }\end{array}$ & - & 4.8 & $\begin{array}{l}60 \% \\
\text { prosthetic } \\
\text { survival at } \\
4.8 \text { years }\end{array}$ & $\begin{array}{l}\text { Harris Hip Score - } \\
33.8 \text { of } 44 \text {, Knee } \\
\text { pain scores }-42.8 \\
\text { of } 50\end{array}$ & $\begin{array}{l}\text { Infection (8), } \\
\text { Dislocation (7), } \\
\text { tibial aseptic } \\
\text { loosening (3) }\end{array}$ \\
\hline 19 & 6 & Mixed & - & 3 & $53 \%$ & $\begin{array}{l}\text { Not reported for } \\
\text { Total Femur }\end{array}$ & $\begin{array}{l}\text { Infection, loosening, } \\
\text { periprosthetic } \\
\text { fracture }\end{array}$ \\
\hline 26 & 15 & $\begin{array}{l}\text { Mixed } \\
\text { (All } \\
\text { tumour } \\
\text { except 2) }\end{array}$ & $38.46 \%$ & & $\begin{array}{l}\text { Prosthetic } \\
\text { revision (3) }\end{array}$ & $\begin{array}{l}\text { Trendelenburg gait } \\
\text { in all-metallic } \\
\text { implants (5), less } \\
\text { gait problem in } \\
\text { allograft-metallic } \\
\text { prosthesis hybrids } \\
\text { (10). }\end{array}$ & $\begin{array}{l}\text { Infection (1), } \\
\text { No dislocations }\end{array}$ \\
\hline 27 & 100 & $\begin{array}{l}\text { Non- } \\
\text { tumour }\end{array}$ & & 5 & $\begin{array}{l}\text { Prosthetic } \\
\text { revision (9), } \\
\text { Amputation } \\
\text { (2). }\end{array}$ & $\begin{array}{l}\text { Enneking } \\
\text { Functional Score } \\
\text { for hip }-3.29 \\
\text { (preop-1.25) and } \\
\text { for knee }-3.29 \\
\text { (preop-2.09); } \\
\text { Trendelenburg gait }\end{array}$ & $\begin{array}{l}\text { Deep infection (12), } \\
\text { dislocation (6), } \\
\text { Material failure (3), } \\
\text { patellar problems } \\
\text { (2), Peroneal nerve } \\
\text { palsy (1) }\end{array}$ \\
\hline 28 & 7 & Tumour & - & - & $\begin{array}{l}100 \% \text { limb } \\
\text { survival at } \\
5 \text { and } 10 \\
\text { years }\end{array}$ & MSTS - 19.5 & - \\
\hline $\begin{array}{l}\text { Present } \\
\text { Study }\end{array}$ & 28 & Tumour & $\begin{array}{l}37 \% \\
\text { (overall) } \\
\text { and } 50 \% \\
\text { (primary } \\
\text { localised } \\
\text { tumour) at } \\
10 \text { years }\end{array}$ & $\begin{array}{l}4.8 \\
\text { (longest } \\
29 \text { years) }\end{array}$ & $\begin{array}{l}92 \% \text { limb } \\
\text { survival } \\
\text { and } \\
80 \% \\
\text { prosthetic } \\
\text { survival at } \\
10 \text { years } \\
\end{array}$ & $\begin{array}{l}\text { MSTS }-21.8 \text { of } \\
30(72.6 \%), \\
\text { TESS }-52.4 \%\end{array}$ & $\begin{array}{l}\text { Loosening (1), } \\
\text { dislocation (3), } \\
\text { deep infection (2), } \\
\text { foot drop (1), } \\
\text { amputation (2) }\end{array}$ \\
\hline
\end{tabular}

Table - 2: Outcomes in Total Femoral Endoprosthetic Replacements in the literature and the present study 


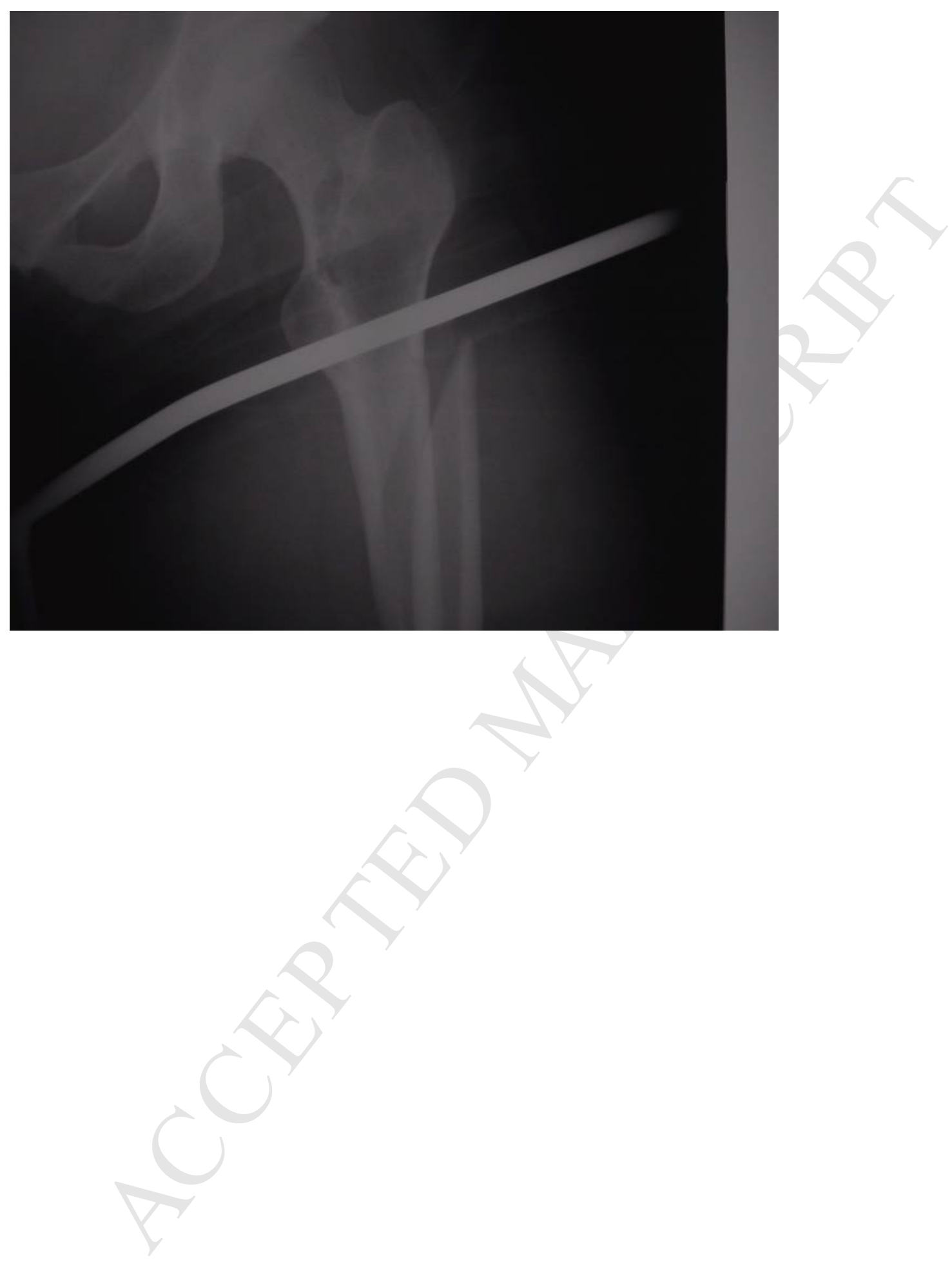




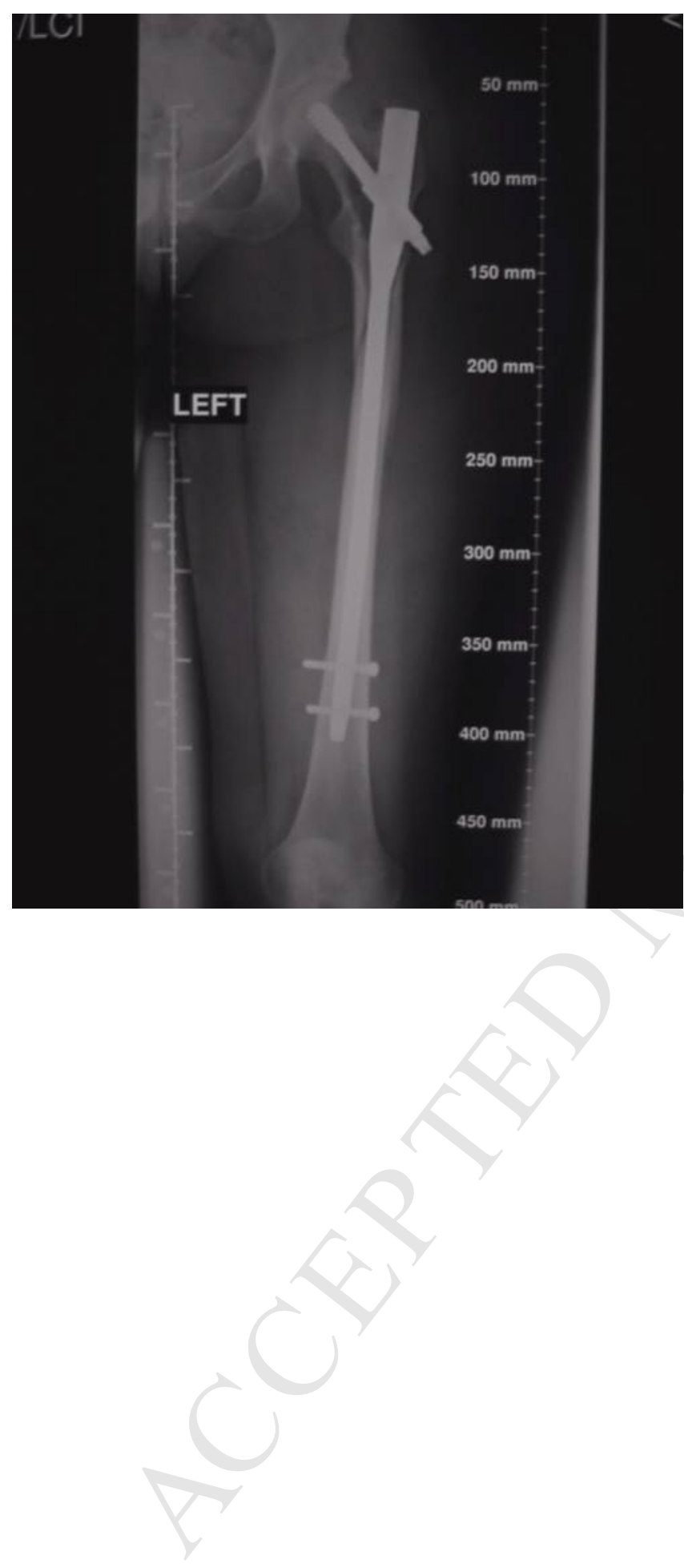




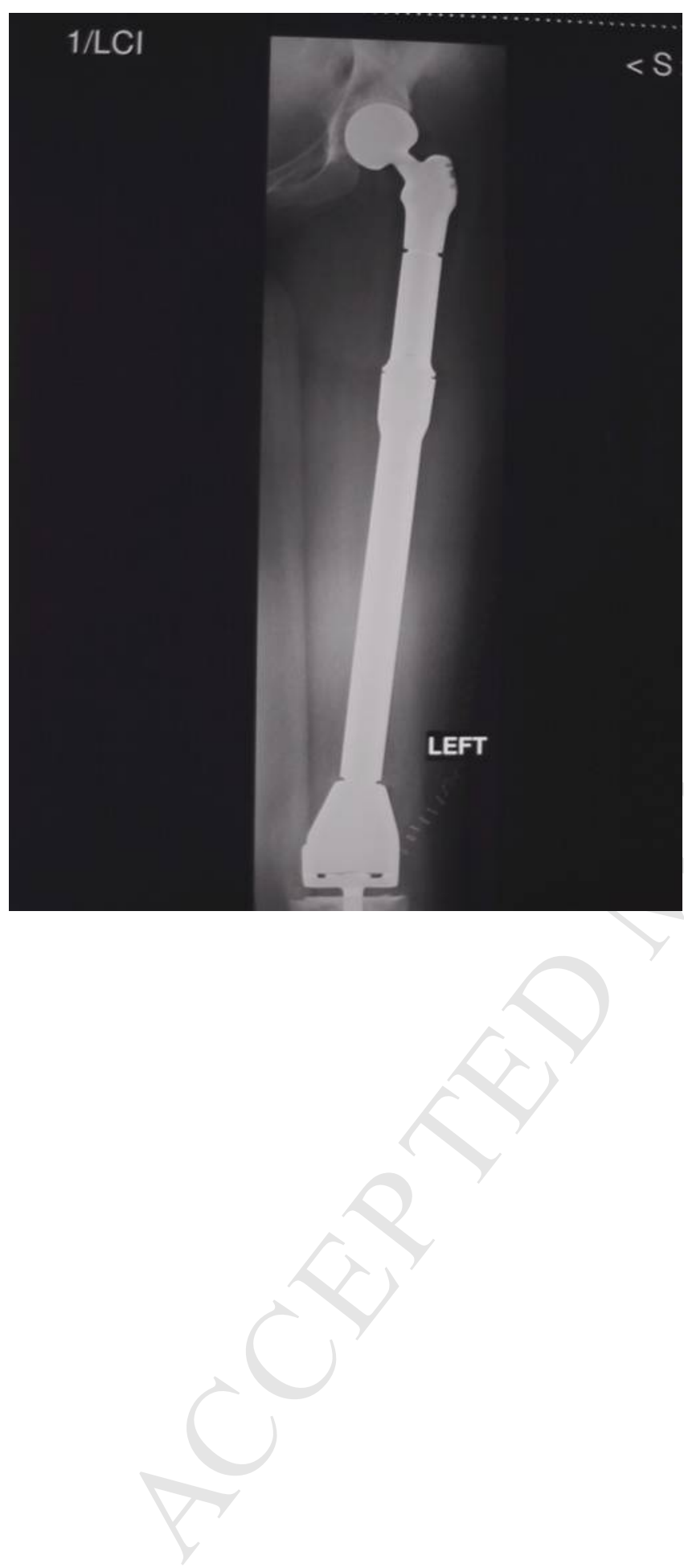




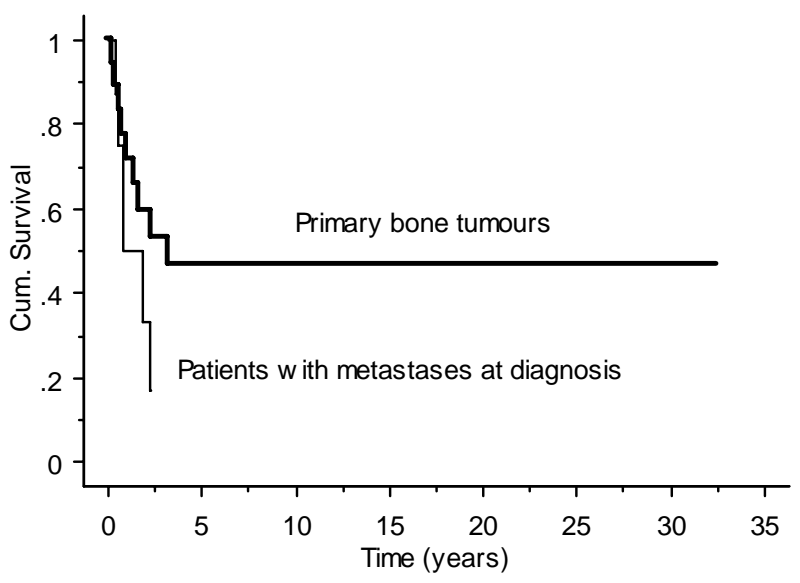

Figure-2: Kaplan Meier survival curve for all patients. 